\title{
Role of Cerebellar Cortical Protein Synthesis in Transfer of Memory Trace of Cerebellum-Dependent Motor Learning
}

\author{
Takehito Okamoto, ${ }^{1,2}$ Shogo Endo, ${ }^{3}$ Tomoaki Shirao, ${ }^{2}$ and Soichi Nagao ${ }^{1,4}$ \\ ${ }^{1}$ Laboratory for Motor Learning Control, RIKEN Brain Science Institute, Hirosawa, Wako, Saitama 351-0198, Japan, ${ }^{2}$ Department of Neurobiology and \\ Behavior, Gunma University Graduate School of Medicine, Showa-machi, Maebashi, Gunma 371-8511, Japan, ${ }^{3}$ Aging Regulation Research Team, Tokyo \\ Metropolitan Institute of Gerontology, Itabashi, Tokyo 173-0015, Japan, and ${ }^{4}$ Solution-Oriented Research for Science and Technology, Japan Science and \\ Technology Corporation, Honcho, Kawaguchi, Saitama, 332-0012, Japan
}

We developed a new protocol that induces long-term adaptation of horizontal optokinetic response (HOKR) eye movement by hours of spaced training and examined the role of protein synthesis in the cerebellar cortex in the formation of memory of adaptation. Mice were trained to view 800 cycles of screen oscillation either by $1 \mathrm{~h}$ of massed training or by $2.5 \mathrm{~h}$ to $8 \mathrm{~d}$ of training with $0.5 \mathrm{~h}$ to $1 \mathrm{~d}$ space intervals. The HOKR gains increased similarly by $20-30 \%$ at the end of training; however, the gains increased by $1 \mathrm{~h}$ of massed training recovered within $24 \mathrm{~h}$, whereas the gains increased by spaced training were sustained over $24 \mathrm{~h}$. Bilateral floccular lidocaine microinfusions immediately after the end of training recovered the gains increased by $1 \mathrm{~h}$ of massed training but did not affect the gains increased by $4 \mathrm{~h}$ of spaced training, suggesting that the memory trace of adaptation was transferred from the flocculus to the vestibular nuclei within $4 \mathrm{~h}$ of spaced training. Blockade of floccular protein synthesis, examined by bilateral floccular microinfusions of anisomycin or actinomycin D 1- $4 \mathrm{~h}$ before the training, impaired the gains increased by $4 \mathrm{~h}$ of spaced training but did not affect the gains increased by $1 \mathrm{~h}$ of massed training. These findings suggest that the transfer of the memory trace of adaptation occurs within $4 \mathrm{~h}$ of spaced training, and proteins synthesized in the flocculus during training period may play an important role in memory transfer.

\section{Introduction}

The memory acquired through spaced learning, i.e., repetitions of learning with appropriate intervals, remains longer than the memory acquired through massed learning. The spacing effect, originally referred by Ebbinghaus (1885), is widely recognized in both the nondeclarative and declarative memory throughout the animal kingdom (Squire and Kandel, 2000). The spacing effect is considered to be closely related to memory consolidation; however, the physiological studies of the underlying neural mechanisms are few, particularly on the mammalian brain. Here, using the spacing effect, we developed a new eye movement training paradigm for mice that induces a long-term adaptation in the horizontal optokinetic response (HOKR) eye movement within $4 \mathrm{~h}$ of training, and we examined the role of protein synthesis in the cerebellar cortex in the formation of motor memory.

The HOKR is a compensatory eye movement to the horizontal motion of the visual field, and its gain is quantified by comparing

Received March 5, 2011; revised May 3, 2011; accepted May 5, 2011.

Author contributions: T.0., S.E., T.S., and S.N. designed research; T.0. performed research; T.0. analyzed data; T.O., S.E., and S.N. wrote the paper.

This study was supported by a Grant-in-Aid from the Japan Society for the Promotion of Science (№. 22300112), the research funds of RIKEN, the Naito Foundation, and Japan Foundation for Aging and Health. We thank Dr. Masao Ito (RIKEN Brain Science Institute, Wako, Saitama, Japan) for critical reading of our manuscript. We also thank Drs. Fumihiro Shutoh (Laboratory of Neuroendocrinology, Graduate School of Comprehensive Human Science, University of Tsukuba, Tsukuba, Ibaraki, Japan) and Tadashi Yamazaki (RIKEN Brain Science Institute-TOYOTA Collaboration (enter, Wako, Saitama, Japan) for helpful suggestions.

Correspondence should be addressed to Soichi Nagao, Laboratory for Motor Learning Control, RIKEN Brain Science Institute, Hirosawa 2-1, Wako, Saitama, 351-0198, Japan. E-mail: nagaos@brain.riken.jp.

DOI:10.1523/JNEUROSCI.1151-11.2011

Copyright $\odot 2011$ the authors $\quad 0270-6474 / 11 / 318958-09 \$ 15.00 / 0$ the evoked eye movement and external surrounding motion. The neural circuitry of the HOKR is composed of the accessory optic tract, cerebellar flocculus, vestibular nuclei, and extraocular muscular motor nuclei. Despite its simple neural circuitry, the HOKR is under learning control (Ito, 1984). Hours of massed training with a sustained exposure to a sufficient amount of retinal slip, i.e., image motion on the retina, adaptively induce an increase in HOKR gains, which recovers within $24 \mathrm{~h}$, in rabbits (Collewijn and Grootendorst, 1979; Nagao, 1983) and mice (Katoh et al., 1998, 2000; Shutoh et al., 2002, 2003, 2006). Results of lesion (Nagao, 1983; Katoh et al., 1998), unit recording (Nagao, 1988), and pharmacological and gene knock-out (Katoh et al., 2000; Shutoh et al., 2002, 2003, 2006) experiments consistently suggest that the flocculus and long-term depression (LTD) of parallel fiber-Purkinje cell synapses (Ito et al., 1982; Ito, 1989, 2001) play a key role in the HOKR adaptation induced by hours of massed training. Moreover, our recent study on mice suggested that a long-term HOKR gain increase, which remains for $>24 \mathrm{~h}$, is induced when $1 \mathrm{~h}$ of massed training is repeated for several days and, concomitantly, the memory trace of adaptation is transferred from the flocculus to the vestibular nuclei (Shutoh et al., 2006). Here, to further reveal the neural mechanisms underlying the transfer of memory trace of adaptation, we first examined the duration of memory of HOKR adaptation induced by training at various spacing intervals and developed a new protocol that induces adaptation of long-term memory by only $4 \mathrm{~h}$ of spaced training in mice. We then confirmed that the transfer of memory trace of adaptation occurs within $4 \mathrm{~h}$ of spaced training by pharmacological shutdown experiments using lidocaine. Finally, we 
examined the role of protein synthesis in the transfer of memory trace of adaptation using protein synthesis inhibitors (anisomycin or actinomycin D). The results suggest that the protein synthesis localized in the cerebellar cortex during the training period may play an important role in the transfer of memory trace that underlies the memory consolidation.

\section{Materials and Methods}

Eye movement measurements. The experimental protocols followed the principles of laboratory animal care (National Institutes of Health publication no. 86-23, revised in 1996) and were approved by the Research Ethics Section of RIKEN. C57BL/6J male mice (12-16 weeks old) obtained from Clea Japan were used in all experiments. All efforts were made to minimize the number of mice used and their suffering throughout the course of experiments. Under isoflurane (Escain, Mylan Japan) anesthesia and aseptic conditions, a platform for head fixation was made on the cranial bone of a mouse using synthetic resin (Superbond C\&B, Sun Medical) and one $15 \mathrm{~mm}$ stainless bolt. After recovery from surgery, the mouse was mounted on the table surrounded by a checked-pattern cylindrical (diameter, $60 \mathrm{~cm}$ ) screen $\left(\right.$ check size, $4^{\circ}$ ) with its head fixed and its body loosely restrained in a plastic tube at the center of a cylindrical screen. Eye movements were recorded using an infrared TV camera (Nagao, 1990; Katoh et al., 1998). The frontal view of the right eye was monitored using a CCD TV camera (SSC-M350; SONY), which was fixed above the mouse, through a cold mirror. The right eye was illuminated by an infrared (wavelength, $920 \mathrm{~nm}$ ) LED and displayed on a 13-inch LCD monitor (magnification, $\times 55$ ). The area of the pupil was determined from the difference in brightness between the pupil and the iris. The real-time position of the eye was measured by calculating the central position of the pupil using an IMAQ (version 6, LabVIEW, National Instruments)-equipped system (Sakatani and Isa, 2004) and stored in a personal computer. Pupil size was kept constant by exposing the mouse to white noise sounds. The mean effective diameter of the mouse eyeball was estimated to be $2.3 \mathrm{~mm}$. The spatial resolution of the TV camera system was $0.25^{\circ}$. The HOKR was examined by 50 cycles of sinusoidal screen oscillation by $15^{\circ}$ (peak-to-peak) at $0.22 \mathrm{~Hz}$ (maximum screen velocity, $10.4 \%$ ) on the horizontal plane in the light. Over 10 cycles of the evoked eye movements, free from blinks and saccades, were selected for averaging. No correction methods were used to delete quick eye movements. Mean amplitudes and phases were calculated on the averaged eye position traces by a modified Fourier analysis (Jastreboff, 1979). HOKR gain was defined as the ratio of the peak-to-peak amplitude of eye movements to that of screen oscillation.

HOKR training protocols. The mice were trained to view 800 cycles of $0.22 \mathrm{~Hz}, 15^{\circ}$ screen oscillation using five different training protocols (Fig. 1). In the massed training $(M)$, mice received 800 cycles of $1 \mathrm{~h}$ continuous screen oscillation. In the spaced training $\left(\mathrm{S}_{0.5 \mathrm{~h}}\right)$, mice received 200 cycles (15 min) of continuous screen oscillation at $0.5 \mathrm{~h}$ intervals four times. In $\mathrm{S}_{1 \mathrm{~h}}$ training, mice received 200 cycles $(15 \mathrm{~min}$ ) of continuous screen oscillation at $1 \mathrm{~h}$ intervals four times. In $\mathrm{S}_{1 \mathrm{~d}-1}$ training, the mice received 200 cycles ( $15 \mathrm{~min}$ ) of continuous screen oscillation at $1 \mathrm{~d}$ intervals four times. In $\mathrm{S}_{1 \mathrm{~d}-2}$ training, the mice received 100 cycles $(7.5 \mathrm{~min}$ ) of continuous screen oscillation at $1 \mathrm{~d}$ intervals eight times. Note that it took $1 \mathrm{~h}$ for $\mathrm{M}, 2.5 \mathrm{~h}$ for $\mathrm{S}_{0.5 \mathrm{~h}}$ and $4 \mathrm{~h}$ for $\mathrm{S}_{1 \mathrm{~h}}$ to complete training. Throughout these five sets of training protocols, the mice were kept in the dark in their home cages except for the sessions of training until they finished training. The HOKR gains were measured on the eye position traces of the initial and final 50 cycles of screen oscillation during each training session and by 50 cycles of screen oscillation from $24 \mathrm{~h}$ to $14 \mathrm{~d}$ after the end of $S_{1 \mathrm{~d}-1}$ training. These mice were reared in their home cages under normal light condition ( $12 \mathrm{~h}$ light/dark) after the end of training.

Lesion experiments. Under isoflurane anesthesia, tiny holes (diameter, 0.5 $\mathrm{mm}$ ) were made on the bilateral temporal bones over the paraflocculus. Bilateral flocculi were lesioned by injecting high-frequency electrical currents $(500 \mathrm{kHz}, 3-5 \mathrm{~mA})$ for 20 s through a small probe (RFG-4A, Radionics) positioned within the flocculus through the holes made on the temporal bones in six mice. Three days after lesioning, these mice were trained using the spaced training at $1 \mathrm{~h}$ intervals $\left(\mathrm{S}_{1 \mathrm{~h}}\right)$. One week later, four of them were

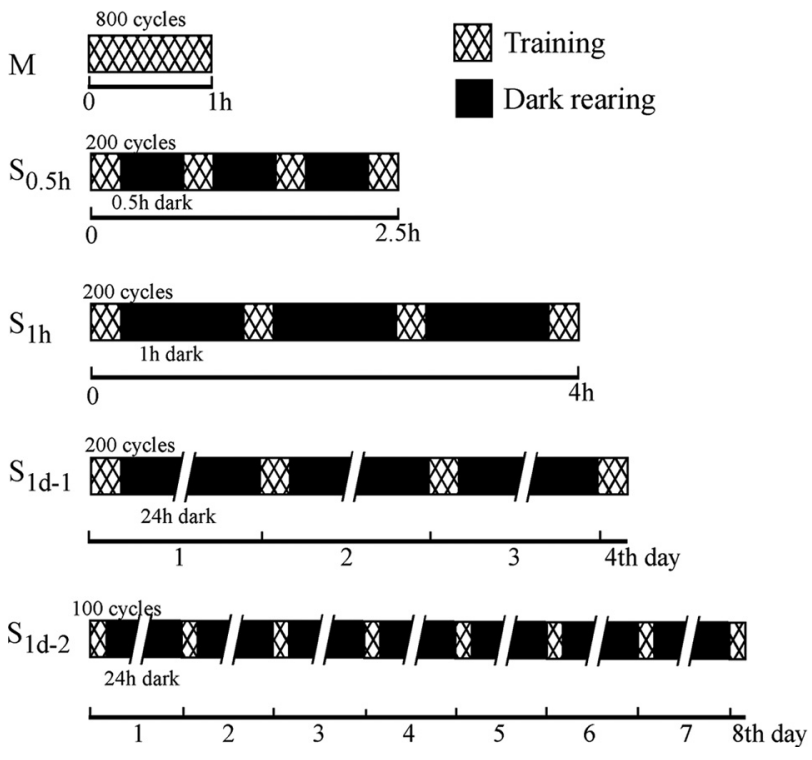

Figure 1. Massed and spaced training protocols for HOKR adaptation. Mice received 800 cycles of $0.22 \mathrm{~Hz}, 15^{\circ}$ screen oscillation by massed $(\mathrm{M})$ training or spaced training at intervals of $0.5 \mathrm{~h}\left(\mathrm{~S}_{0.5 \mathrm{~h}}\right), 1 \mathrm{~h}\left(\mathrm{~S}_{1 \mathrm{~h}}\right)$, and $24 \mathrm{~h}\left(\mathrm{~S}_{1 \mathrm{~d}-1}\right.$ and $\left.\mathrm{S}_{1 \mathrm{~d}-2}\right)$. Total time of $2.5 \mathrm{~h}, 4 \mathrm{~h}, 4 \mathrm{~d}$, and $8 \mathrm{~d}$ for $\mathrm{S}_{0.5 \mathrm{~h}}$ $S_{1}, S_{1 d-1}$, and $S_{1 d-2,}$, respectively, is required to complete each training protocol. Except for sessions of training, the mice were kept in the dark.

again trained using the spaced training at $1 \mathrm{~d}$ intervals $\left(\mathrm{S}_{1 \mathrm{~d}-1}\right)$. At the end of experiments, under deep general anesthesia induced by intraperitoneal administration of $60 \mathrm{mg} /$ body weight sodium pentobarbital (Nembutal, Dainippon-Sumitomo Pharma), all the mice were perfused with PBS and $4 \%$ paraformaldehyde. The extents of lesions were examined histologically on Nissl-stained, $20-\mu \mathrm{m}$-thick coronal sections.

Pharmacological experiments. The effects of flocculus shutdown were compared in 17 mice. They received massed training $(\mathrm{M}, n=11)$ or spaced training at $1 \mathrm{~h}$ intervals $\left(\mathrm{S}_{1 \mathrm{~h}}, n=6\right)$. At the end of the training, $0.4 \mu \mathrm{l}$ of $2.5 \%$ lidocaine chloride (Sigma-Aldrich) dissolved in standard Ringer's solution was infused into the bilateral flocculi $(0.2 \mu \mathrm{l}$ for each side) using two $1 \mu \mathrm{l}$ microsyringes (80135, Hamilton) mounted on standard micromanipulators. Infusion was finished within $10 \mathrm{~min}$. The HOKR was measured $0.5,1$, and $1.5 \mathrm{~h}$ after infusions. Except for the session for the training and measurements of HOKR, the mice were kept in the dark in their home cages. Infusions of lidocaine were also examined in six additional mice that received $S_{0.5 \mathrm{~h}}$ training.

The role of protein synthesis in HOKR adaptation was examined by infusion of $0.8 \mu \mathrm{l}(0.4 \mu \mathrm{l}$ for each side) of anisomycin (125 $\mu \mathrm{g} / \mu \mathrm{l}$, SigmaAldrich) dissolved in Ringer's solution at $\mathrm{pH} 7$ by referring to Nader et al. (2000) on the study of rat amygdala. The drugs were infused into the bilateral flocculi similarly as lidocaine $4 \mathrm{~h}$ before the initiation of massed training $(\mathrm{M}$, $n=6)$ or $1 \mathrm{~h}$ before the initiation of spaced training at $1 \mathrm{~h}$ intervals $\left(\mathrm{S}_{1 \mathrm{~h}}, n=\right.$ 6). As a control, the same amount of Ringer's solution was infused into the bilateral flocculi before the same training sessions ( $\left.\mathrm{M}, n=5 ; \mathrm{S}_{1 \mathrm{~h}}, n=5\right)$. In 6 mice, HOKR gains were measured $6 \mathrm{~h}$ and $24 \mathrm{~h}$ after infusions of anisomycin without any training. We also infused $0.8 \mu \mathrm{l}$ ( $0.4 \mu \mathrm{l}$ for each side) of actinomycin D $(6.25 \mu \mathrm{g} / \mu \mathrm{l}$, Sigma-Aldrich) dissolved in Ringer's solution into the bilateral flocculi $(n=6) 1 \mathrm{~h}$ before the initiation of $S_{1 \mathrm{~h}}$ training by referring to Lin et al. (2003) on the study of rat amygdala.

After the end of experiments, $1 \%$ fluorescein isothiocyanate hydrochloride (FITC, Research Organics) dissolved in dimethyl sulfoxide (Merck Japan) was infused into the bilateral flocculi similarly as infusions of lidocaine, anisomycin, or actinomycin D to estimate the extent of drug diffusion. The mice were perfused under pentobarbital anesthesia $(60 \mathrm{mg}$ /kg body weight, Nembutal, Dainippon Sumitomo Pharma). Drug diffusions were examined histologically on coronal sections under a fluorescence microscope (BX50, Olympus).

Histological inspections of the flocculus after anisomycin infusions were carried out in seven mice. For four mice, $0.4 \mu \mathrm{l}$ of anisomycin and 
the same amount of Ringer's solution was infused into the right and left flocculi, respectively. The other three mice were used for noninfusion control. They were kept in the dark without any training and then perfused under the pentobarbital anesthesia $24 \mathrm{~h}$ after infusions. The total number of Purkinje cells and the general cortical structure were compared on Nissl-stained coronal sections (thickness, $12 \mu \mathrm{m}$ ) for the anisomycininfused, Ringer's solution-infused, and noninfused flocculi. The significance of the data obtained in the whole series of experiments was evaluated using Statview (version 5, SAS Institute).

\section{Results}

Spacing effect in HOKR adaptation

To examine the spacing effect in HOKR adaptation, we trained $\mathrm{C} 57 \mathrm{BL} / 6 \mathrm{~J}$ mice to view 800 cycles of $0.22 \mathrm{~Hz}, 15^{\circ}$ screen oscillation in the head-fixed position using five different training protocols (Fig. 1). One group of mice received 800 cycles of massed training in $1 \mathrm{~h}(\mathrm{M}, n=11)$, whereas the three spaced training groups received $4 \times 200$ cycles of training at $0.5 \mathrm{~h}$ $\left(\mathrm{S}_{0.5 \mathrm{~h}}, n=5\right), 1 \mathrm{~h}\left(\mathrm{~S}_{1 \mathrm{~h}}, n=9\right)$, and $1 \mathrm{~d}$ $\left(\mathrm{S}_{1 \mathrm{~d}-1}, n=7\right)$ intervals, and the remaining group received 100 cycles of training at $1 \mathrm{~d}$ intervals for $8 \mathrm{~d}\left(\mathrm{~S}_{1 \mathrm{~d}-2}, n=5\right)$. These mice were kept in the dark during intervals and thus they received no additional visual inputs. We first measured the HOKR gain and then trained the mice to induce adaptation in gain. The HOKR gains (mean \pm $\mathrm{SE})$ at the start of training were similar among the five groups (from $0.28 \pm 0.01$ to $0.32 \pm 0.02, p>0.25$, one-factorial ANOVA) (Table 1). The HOKR gain increase $(\%)$ is normalized to the mean gain at the start of training. Figure 2 shows a comparison of the gain increase among five training protocols. The gain increase fluctuated among training sessions, and a tendency of small gain increase was often observed in the spacing intervals (Fig. $2 B, C)$. At the end of five training sessions, the HOKR gains increased similarly by $22.1-31.2 \%$. The retention of memory of adaptation was examined $24 \mathrm{~h}$ after the end of the training sessions. The HOKR gain increased by $1 \mathrm{~h}$ of massed training (Fig. $2 A, F)$ decreased by one-half $(p<0.02$, paired $t$ test), whereas the gain increased by all four spaced training protocols $\left(\mathrm{S}_{0.5 \mathrm{~h}}-\mathrm{S}_{1 \mathrm{~d}-2}\right)$, remained unchanged for $24 \mathrm{~h}$ (Fig. $2 B-F, p>0.5-0.9$, paired $t$ test). Thus, the spacing effect is clearly observed in the retention of HOKR adaptation.

We examined the recovery of HOKR adaptation for the five mice that received $\mathrm{S}_{1 \mathrm{~d}-1}$ training every $3 \mathrm{~d}$ up to $14 \mathrm{~d}$ after the end of training. These mice were reared under normal light condition (12 h, light/dark) without any other optokinetic training after the end of $\mathrm{S}_{1 \mathrm{~d}-1}$ training, except for the brief time for the measurements of HOKR. The gain increase remained for $10 \mathrm{~d}$ after the end of $\mathrm{S}_{1 \mathrm{~d}-1}$ training (16.2-24.1\%, $p<0.05$, Dunnett's test; compared with the gains before the training), and a tendency of small gain increase $(10.6 \pm 3.3 \%, p>0.05)$ was observed $14 \mathrm{~d}$ after the end of $S_{1 \mathrm{~d}-1}$ training, which was similar to our previous study using $5 \mathrm{~d}$ of 600
Table 1. Mean HOKR gain (SE) to $0.22 \mathrm{~Hz}, 1^{\circ}$ (peak-to-peak) screen oscillation at the start of 5 training sessions

\begin{tabular}{llllll}
\hline Training & $\mathrm{M}(n=11)$ & $\mathrm{S}_{0.5 \mathrm{~h}}(n=5)$ & $\mathrm{S}_{1 \mathrm{~h}}(n=9)$ & $\mathrm{S}_{1 \mathrm{~d}-1}(n=7)$ & $\mathrm{S}_{1 \mathrm{~d}-2}(n=5)$ \\
\hline Gain (SE) & $0.30(0.01)$ & $0.28(0.01)$ & $0.28(0.02)$ & $0.32(0.02)$ & $0.32(0.02)$ \\
\hline
\end{tabular}

The gains at the start of training were similar among the 5 groups ( $p>0.25$, one-factorial ANOVA).
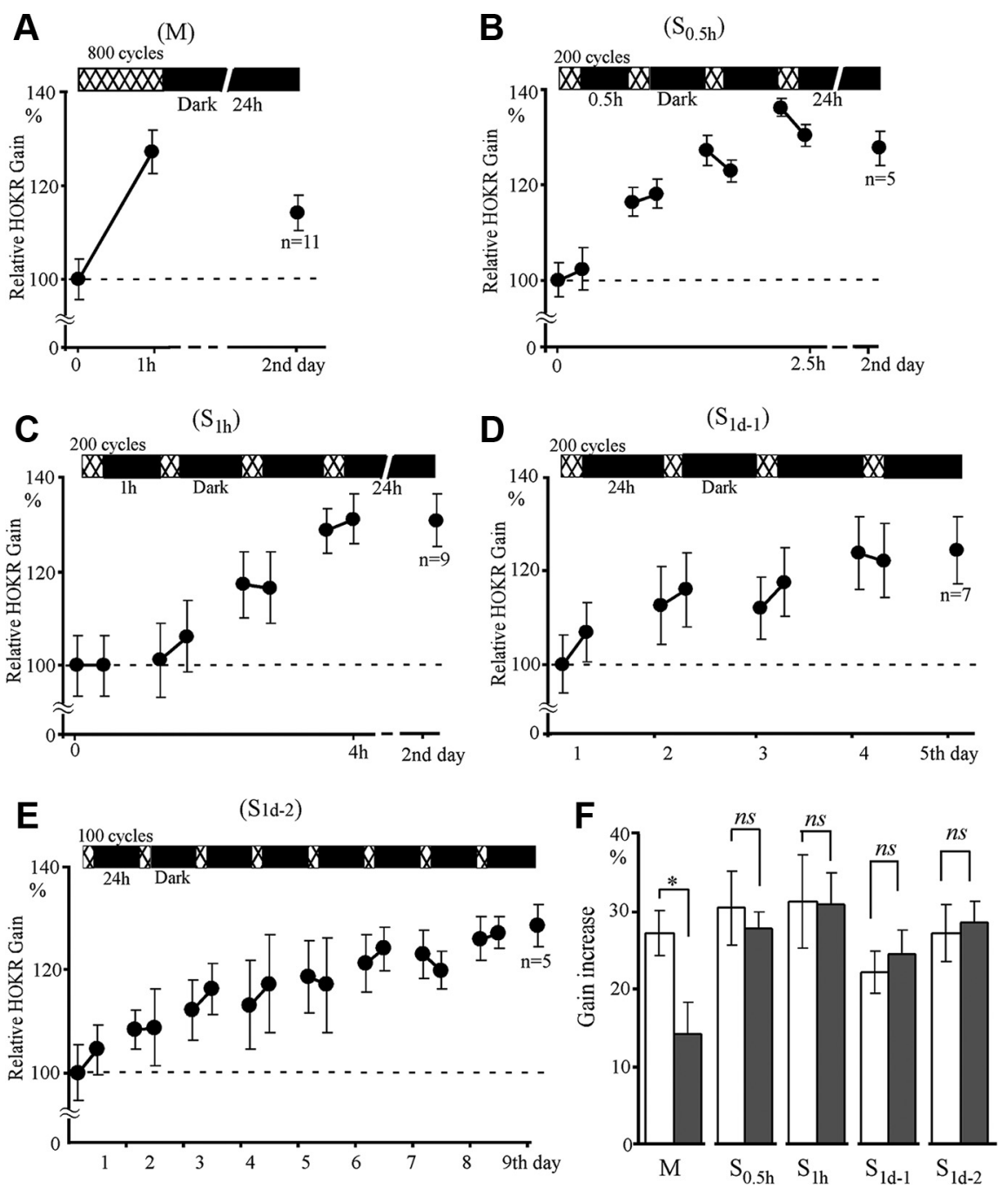

Figure 2. HOKRadaptation induced by massed and spaced training protocols. Mice were trained using $800 \mathrm{cycles}$ of $0.22 \mathrm{~Hz}, 15^{\circ} \mathrm{screen}$ y cycles at 1 d intervals $\left(S_{1 \mathrm{~d}-1,}, n=7\right)$. $\boldsymbol{E}$, Spaced training with $8 \times 100$ cycles at 1 d intervals $\left(S_{1 \mathrm{~d}-2,}, n=5\right)$. $\boldsymbol{F}$, Comparison of gain increase immediately after (open columns) and $24 \mathrm{~h}$ after (filled columns) the end of training among the five protocols. The HOKR gain increase (\%) is normalized to the mean gain at the start of training. Error bars indicate SE; ${ }^{*} p<0.05 ; n s, p>0.05$ (paired $t$ test).

cycles of $0.17 \mathrm{~Hz}-15^{\circ}$ screen oscillation at $1 \mathrm{~d}$ intervals (Shutoh et al., 2006). The HOKR phases were not affected by any of the five training protocols, and are not discussed in this article.

\section{Effects of floccular lesions on spaced training-induced HOKR adaptation}

We previously reported that the HOKR adaptation induced by $1 \mathrm{~h}$ (600 cycles) of massed training with $0.17 \mathrm{~Hz}, 15^{\circ}$ screen oscillation is abolished by bilateral cerebellar flocculus lesions in mice (Katoh et al., 1998; Shutoh et al., 2006). To confirm these findings in the HOKR adaptation induced by the spaced training, we carried out lesion experiments. We made bilateral floccular lesions in six mice by the electric coagulation method $3 \mathrm{~d}$ before 
A

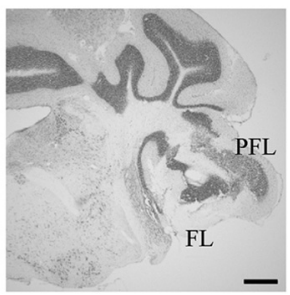

B

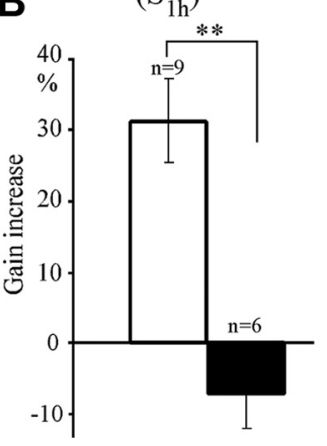

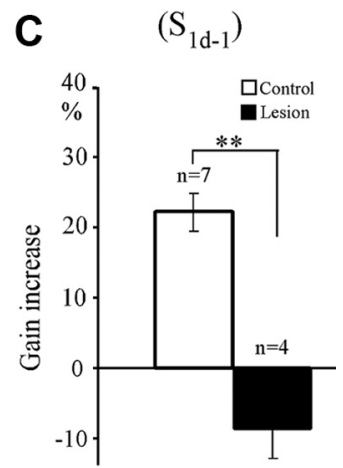

Figure 3. Effects of bilateral floccular lesions on HOKR adaptation induced by spaced training. $A$, Photograph of coronal section of right paraflocculus (PFL) and flocculus (FL) after lesioning. Scale bar, $500 \mu \mathrm{m}$. B, HOKR gain increase after $4 \times 200$ cycles of screen oscillation at $1 \mathrm{~h}$ intervals $\left(S_{1 \mathrm{~h}}\right)$ for lesioned mice (filled column, $n=6$ ). Control data (open column, $n=9$ ) are those shown in Figure 2 C. C, Similar to $B$ but after $4 \times 200$ cycles of screen oscillation at 1 dintervals $\left(S_{1 d}, n=4\right)$. Control data $(n=7)$ are those shown in Figure 2D. ${ }^{* *} p<0.01$ (Student's $s$ test). Error bars indicate SE.

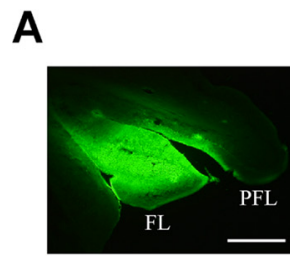

B
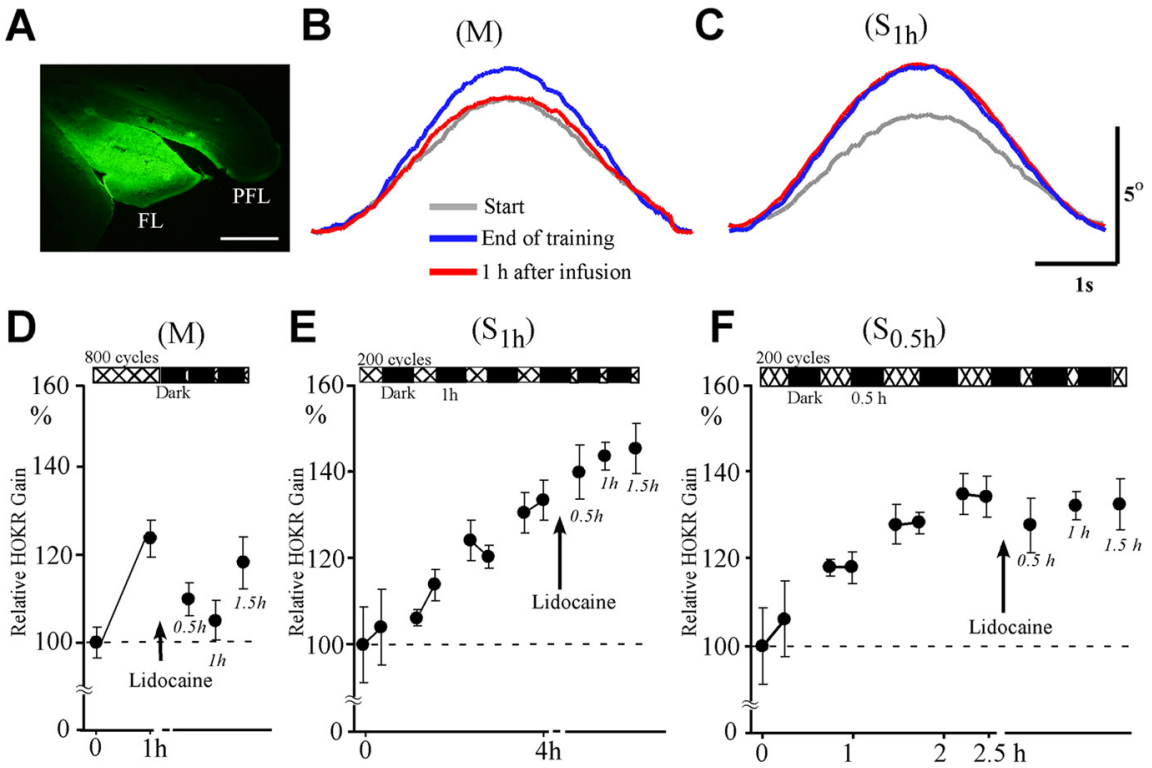

G

(M)

\section{H}

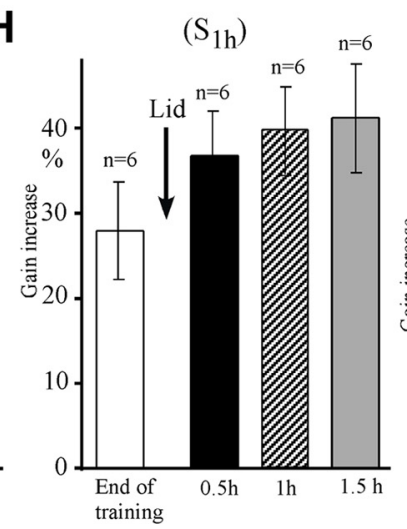

I

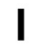

\section{$\left(\mathrm{S}_{0.5 \mathrm{~h}}\right)$}

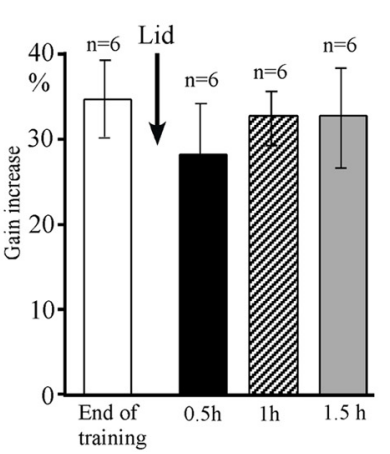

Figure 4. Effects of reversible shutdown of bilateral flocculi on adaptation induced by 800 cycles of massed training $(M)$ and spaced training using $4 \times 200$ cycles at $1 \mathrm{~h}$ intervals $\left(\mathrm{S}_{1 \mathrm{~h}}\right)$. $A$, Extension of lidocaine diffusion estimated by FITC infusion. FL, Flocculus. PFL, paraflocculus. Scale bar, $500 \mu \mathrm{m}$. B, Example of eye position traces before training (gray curve), at the end of training (blue curve), and $1 \mathrm{~h}$ after infusion of lidocaine (red curve) during $M$ training. Averaged eye position traces from 16 to 25 cycles obtained from the same mouse are shown. $C$, Similar to $B$ but for those during $S_{1 \mathrm{~h}}$ training. Averaged eye position traces from 16 to 27 cycles obtained from the same mouse are shown. Scale bars, $1 \mathrm{~s}$ and $5^{\circ}$. D $\boldsymbol{F}$, Time course of HOKR adaptation and effects of floccular lidocaine infusions for $M(D), S_{1 \mathrm{~h}}(\boldsymbol{E})$, and $\mathrm{S}_{0.5 \mathrm{~h}}(\boldsymbol{F})$ training. $G$, Comparison of gain increase at the end of $M$ training, $0.5 \mathrm{~h}, 1 \mathrm{~h}$, and $1.5 \mathrm{~h}$ after lidocaine (Lid) infusions $(n=6-11) . \boldsymbol{H}, \boldsymbol{I}$, Similar to $\mathbf{G}$ but for those of $\mathrm{S}_{1 \mathrm{~h}}$ training $(\boldsymbol{H}, n=6)$ and $\mathrm{S}_{0.5} \mathrm{~h}$ training $(I, n=6) .{ }^{*} p<0.05$ (Dunnett's test). Error bars indicate SE.

the training. In these mice, $>75 \%$ of the paraflocculus and flocculus region was destroyed bilaterally, whereas the vestibular nerve and nuclei remained intact (Fig. $3 A$ ). We used data obtained with normal mice shown in Figure 2, $C$ and $D$, as the control as in our previous studies (Katoh et al., 1998; Shutoh et al., 2006). The HOKR gain at $0.22 \mathrm{~Hz}-15^{\circ}$ screen oscillation after floccular lesions $(0.24 \pm 0.01$, $n=10)$ was small ( $p<0.01$, Student's $t$ test) compared with the control group $(0.30 \pm 0.01, n=16)$. We trained the mice using $4 \times 200$ cycles of $0.22 \mathrm{~Hz}, 15^{\circ}$ screen oscillation at $1 \mathrm{~h}\left(\mathrm{~S}_{1 \mathrm{~h}}\right)$ or $1 \mathrm{~d}\left(\mathrm{~S}_{1 \mathrm{~d}-1}\right)$ intervals. The HOKR gain decreased slightly after $S_{1 \mathrm{~h}}(-7.1 \pm 5.0 \% n=6)$ (Fig. $3 B$ ) or $\mathrm{S}_{1 \mathrm{~d}-1}(-8.5 \pm 4.5 \% n=4)$ (Fig. $3 C$ ) training. These gain changes were both statistically significant compared with the data for the control group shown in Figure 1, $C$ and $D(p<0.01$, Student's $t$ test $)$. Thus, the flocculus is necessary for the HOKR adaptation induced by spaced training through $S_{1 \mathrm{~h}}$ and $\mathrm{S}_{1 \mathrm{~d}-\mathrm{l}}$.

Effects of reversible flocculus shutdown on HOKR adaptation after training On the basis of findings of our previous study (Shutoh et al., 2006) in which the effects of pharmacological floccular shutdown on HOKR adaptation were examined, we suggested that the memory trace of HOKR adaptation induced by $1 \mathrm{~h}(600$ cycles) of $0.17 \mathrm{~Hz}, 5^{\circ}$ screen oscillation training is located in the flocculus and that the memory trace is transferred to the vestibular nuclei after repetition of $1 \mathrm{~h}$ of training for $3 \mathrm{~d}$. In the present study, we found that the duration of memory for adaptation induced by $S_{0.5}$ and $S_{1} h$ spaced training protocols is longer than that of $1 \mathrm{~h}$ of $\mathrm{M}$ training. It took 2.5 and $4 \mathrm{~h}$ for $\mathrm{S}_{0.5 \mathrm{~h}}$ and $\mathrm{S}_{1 \mathrm{~h}}$ training protocols to be completed, respectively (Fig. 1). Thus, it is possible that the memory trace of adaptation is transferred from the flocculus to the vestibular nuclei within 2.5 to $4 \mathrm{~h}$ during these spaced training protocols. Then, we examined the location of the memory trace of adaptation induced by the spaced training $\left(\mathrm{S}_{1 \mathrm{~h}}\right)$ by bilateral pharmacological floccular shutdown immediately after the end of training sessions.

We compared the effects of lidocaine infusions on the HOKR adaptation between $\mathrm{M}$ and $\mathrm{S}_{1 \mathrm{~h}}$ training protocols. The mean HOKR gains before training were similar between $\mathrm{M}(0.30 \pm 0.01, n=11)$ and $S_{1 h}(0.29 \pm 0.02, n=6 ; p>0.2$, Student's $t$ test) training sessions, and the gain increase induced by these training protocols were also similar $(23.7 \pm 1.9 \%$ 
Table 2. Mean HOKR gain (SE) to $0.22 \mathrm{~Hz}, 1^{\circ}$ (peak-to-peak) screen oscillation before and 1-24 $\mathrm{h}$ after floccular infusions of anisomycin

\begin{tabular}{llllll}
\hline & Before infusions $(n=18)$ & $1 \mathrm{~h}(n=6)$ & $4 \mathrm{~h}(n=6)$ & $6 \mathrm{~h}(n=6)$ & $24 \mathrm{~h}(n=6)$ \\
\hline Gain (SE) & $0.28(0.01)$ & $0.25(0.01)$ & $0.28(0.03)$ & $0.30(0.01)$ & $0.30(0.02)$ \\
\hline
\end{tabular}

The gains after infusions were similar to those before infusions ( $p>0.05$, Dunnett's test).

Table 3. Mean (SE) number of floccular Purkinje cells $24 \mathrm{~h}$ after floccular drug infusions and noninfused control

\begin{tabular}{llll}
\hline & $\begin{array}{l}\text { Anisomycin } \\
(n=4)\end{array}$ & $\begin{array}{l}\text { Ringer's solution } \\
(n=4)\end{array}$ & $\begin{array}{l}\text { Control } \\
(n=3)\end{array}$ \\
\hline Number of Purkinje cells (SE) & $678(22)$ & $696(22)$ & $730(47)$
\end{tabular}

The numbers of floccular Purkinje cells were counted in the anisomycin-infused right side and Ringer's solutioninfused left side on 25-30 Nissl-stained coronal serial sections (thickness, $12 \mu \mathrm{m}$ ) in four mice, and those for noninfused control were counted similarly from three naive mice.

for $M$ vs $27.9 \pm 5.7 \%$ for $S_{1 h}, p>0.3$, Student's $t$ test). We infused $0.4 \mu \mathrm{l}(0.2 \mu \mathrm{l}$ for each side) of $2.5 \%$ lidocaine into the bilateral flocculi immediately after the end of training. The infused lidocaine covered the entire flocculus $1 \mathrm{~h}$ after infusion, and this was confirmed by $0.4 \mu \mathrm{l}(0.2 \mu \mathrm{l}$ for each side $)$ infusions of FITC carried out similarly as lidocaine infusions (Fig. 4A). We did not observe any nystagmus-like or slow-drift eye movements when we examined the HOKR $30 \mathrm{~min}$ after the end of infusions. The mean number of eye position traces free from saccades in 50 cycles of screen oscillation did not differ before and after infusions ( $20 \pm 1$ vs $22 \pm 1, n=23$ infusions; $p>0.1$, paired $t$ test). The gain increase induced by $\mathrm{M}$ training decreased 0.5 and $1 \mathrm{~h}$ after infusions ( $p<0.05$, Dunnett's test) (Fig. $4 B, D, G)$, and recovered to the level of end of training $1.5 \mathrm{~h}$ after infusions $(p>$ $0.05)$. We consider that the recovery at $1.5 \mathrm{~h}$ may be due to the decline of anesthetic action of lidocaine. By contrast, the gain increase induced by $\mathrm{S}_{1 \mathrm{~h}}$ training was not affected $0.5-1.5 \mathrm{~h}$ after infusions $(p>0.05)$ (Fig. $4 C, E, H)$. These findings indicate that the memory trace of adaptation induced by $M$ training was maintained within the flocculus at the end of training, but that induced by $S_{1 \mathrm{~h}}$ training was no longer located there at the end of training. We also examined the effects of flocculus shutdown on the HOKR adaptation induced by $S_{0.5 \mathrm{~h}}$ training and obtained similar results as those for $\mathrm{S}_{1 \mathrm{~h}}$ training (Fig. $4 F, I$ ). Thus, the transfer of memory trace of adaptation occurs rather fast, within $2.5-4 \mathrm{~h}$ of training, when space intervals are inserted.

\section{Effects of floccular protein synthesis blockade on HOKR adaptation}

We then examined pharmacologically whether the de novo floccular protein synthesis plays a role in the HOKR adaptation induced by $\mathrm{M}$ and $\mathrm{S}_{1 \mathrm{~h}}$ training protocols. We infused $0.8 \mu \mathrm{l}(0.4 \mu \mathrm{l}$ for each side) of anisomycin $(125 \mu \mathrm{g} / \mu \mathrm{l})$ or control Ringer's solution into the bilateral flocculi by referring to the experiments on rat fear conditioning (Nader et al., 2000; Debiec et al., 2002). We measured the nonadapted HOKR gains at 1, 4, 6, and $24 \mathrm{~h}$ after bilateral floccular anisomycin infusions. No differences were observed on HOKR gains for $24 \mathrm{~h}$ after infusions, compared with those before infusions ( $p>0.05$, Dunnett's test) (Table 2). The total number of floccular Purkinje cells, which were counted histologically $24 \mathrm{~h}$ after infusions, was around 700, and no differences were observed among anisomycin-infused, Ringer's solution-infused, or noninfused flocculi $(p>0.05$, TukeyKramer test) (Table 3). Furthermore, the general cortical structures were not altered by infusions of anisomycin except for the track of the infusion needle tip (Fig. 5A). The diffusion of drugs was examined using $0.4 \mu \mathrm{l}$ of FITC infusions similarly as in Figure
$4 A$. The infused FITC diffused within the flocculus and did not reach the brainstem region, both 1 and $5 \mathrm{~h}$ after infusions (data not shown in figures).

$\mathrm{M}$ training started $4 \mathrm{~h}$ after the infusions of drugs, $\mathrm{S}_{1 \mathrm{~h}}$ training started $1 \mathrm{~h}$ after the infusions, and both finished $5 \mathrm{~h}$ after the infusions. The HOKR gains at the start of training were similar between Ringer's solution $(0.26 \pm 0.02, n=12)$ and anisomycin $(0.27 \pm 0.02, n=10)$ infusions. The gain increase induced by $\mathrm{M}$ training was similar between Ringer's solution $(32.5 \pm 3.7 \%, n=$ $5)$ and anisomycin $(22.5 \pm 5.4 \%, n=6 ; p>0.1$, Student's $t$ test $)$ infusions (Fig. $5 B, D, F$ ) and was within the range of gain increase shown in Figure 2. The increased gain declined $24 \mathrm{~h}$ after the end of training in Ringer's solution-infused mice $(18.0 \pm 4.3 \%$ vs $32.5 \pm 3.7 \%, n=5, p<0.05$, paired $t$ test) but did not decline in anisomycin-infused mice $(22.5 \pm 5.4 \%$ vs $32.5 \pm 4.6 \%, n=6$, $p>0.05$ ) (Fig. $5 F$ ). Thus, anisomycin did not impair the adaptation induced by massed training but affected its retention.

In contrast, the gain increase induced by $\mathrm{S}_{1 \mathrm{~h}}$ training in anisomycin-infused mice $(9.2 \pm 8.4 \%, n=6)$ was significantly smaller than that in Ringer's solution-infused mice (37.5 $\pm 8.0 \%$, $n=5 ; p<0.05$, Dunnett's test) (Fig. $5 C, E, G$ ). However, the HOKR gain increase measured $24 \mathrm{~h}$ after the end of $S_{1 \mathrm{~h}}$ training was similar between anisomycin-infused $(41.2 \pm 9.1 \%, n=6)$ and Ringer's solution-infused (34.4 $\pm 8.7 \%, n=5, p>0.05$, Dunnett's test) (Fig. 5C,E) mice. Thus, anisomycin infusions inhibited the adaptation induced by $S_{1}$ h training, but very little affected the adaptation induced by $\mathrm{M}$ training. The inhibitory effect of anisomycin on the adaptation induced by $S_{1 \mathrm{~h}}$ recovered $24 \mathrm{~h}$ after training.

We also infused $0.8 \mu \mathrm{l}(0.4 \mu \mathrm{l}$ for each side $)$ of actinomycin D $(6.25 \mu \mathrm{g} / \mu \mathrm{l})$ into the bilateral flocculi $1 \mathrm{~h}$ before $\mathrm{S}_{1 \mathrm{~h}}$ training in 6 mice (Fig. $5 E, G$ ). The HOKR gains were not different before $(0.27 \pm 0.01)$ and after $(0.26 \pm 0.01)$ the infusions. The gain increase at the end of $S_{1 \mathrm{~h}}$ training in actinomycin D-infused mice (9.1 $\pm 5.6 \%, n=6 ; p<0.05$, Dunnett's test) was also small compared with that in Ringer's solution-infused mice (34.4 \pm $8.7 \%, n=5)$. The depression of gain increase continued $24 \mathrm{~h}$ after the end of training $(2.7 \pm 4.7 \%, n=6$; $p<0.05)$, unlike anisomycin infusions. Thus, the actinomycin D infusions impaired the HOKR adaptation induced by $S_{1 \mathrm{~h}}$ training, without any recovery $24 \mathrm{~h}$ after training.

\section{Discussion}

We compared the duration of memory of HOKR adaptation in five groups of mice that were trained by 800 cycles of screen oscillation with or without intervals (Fig. 1). After the end of training sessions, the HOKR gains increased similarly in all the groups, and the spacing effect was demonstrated in term of the retention of adapted gains after $24 \mathrm{~h}$ (Fig. 2). By using the spacing effect, we developed a protocol that produces a long-term memory in HOKR adaptation by $4 \mathrm{~h}$ of spaced training. We confirmed that the cerebellar flocculus is necessary for the adaptation induced by $4 \mathrm{~h}$ of spaced training by lesion experiments (Fig. 3 ) and that the memory trace of the adaptation is transferred from the flocculus to vestibular nuclei within 2.5 to $4 \mathrm{~h}$ of spaced training by pharmacological experiments (Fig. 4). We revealed that the pharmacological blockade of floccular protein synthesis did not affect the adaptation induced by $1 \mathrm{~h}$ of massed training, but it impaired the adaptation induced by $4 \mathrm{~h}$ of spaced training (Fig. 5), suggesting that the de novo floccular protein synthesis may be necessary for the transfer of the memory trace that underlies the consolidation of motor memory. The retention of memory induced by $1 \mathrm{~h}$ of massed training was affected by blockade of 
A

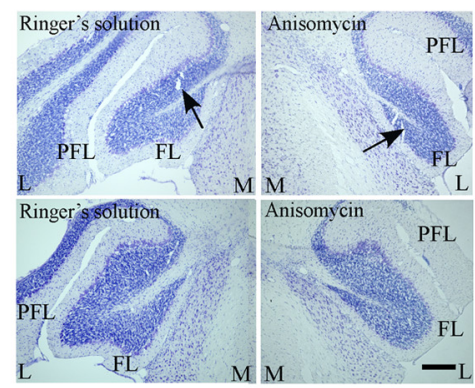

B

(M)

C $\left(\mathrm{S}_{1 \mathrm{~h}}\right)$
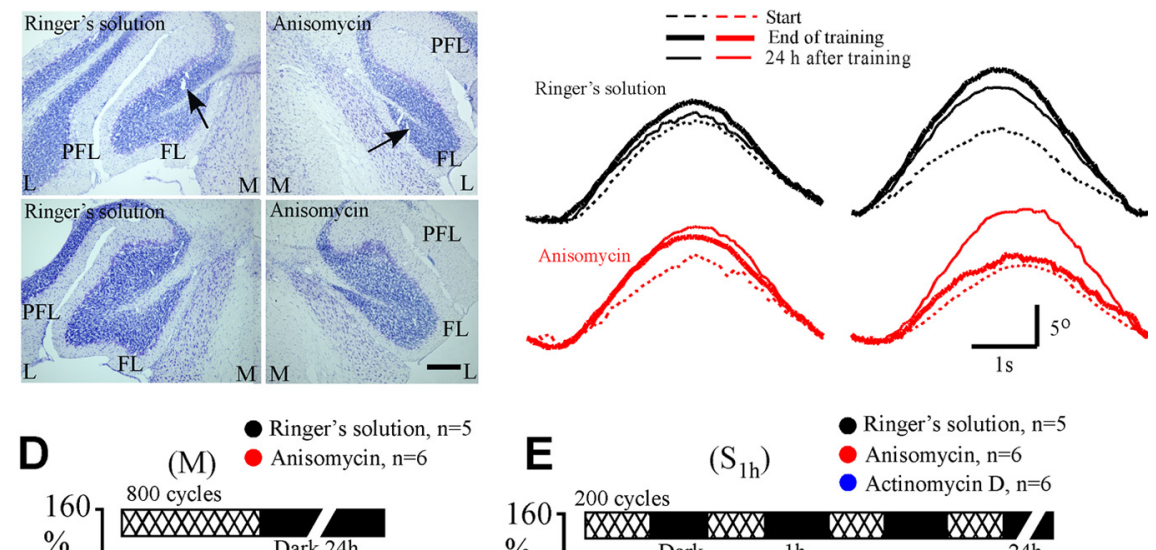

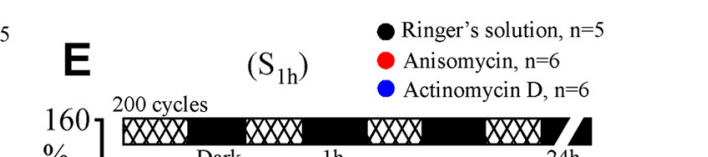

$\% \quad \frac{1 \mathrm{~m}}{\text { Dark }} \mathrm{lh} \quad 24 \mathrm{~h}$

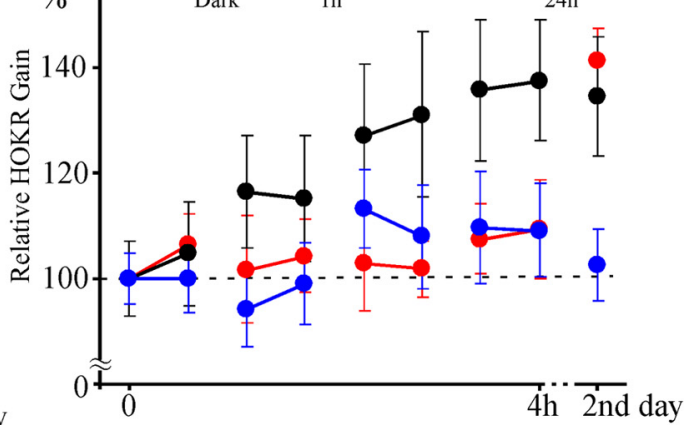

$\mathbf{F}$

(M)

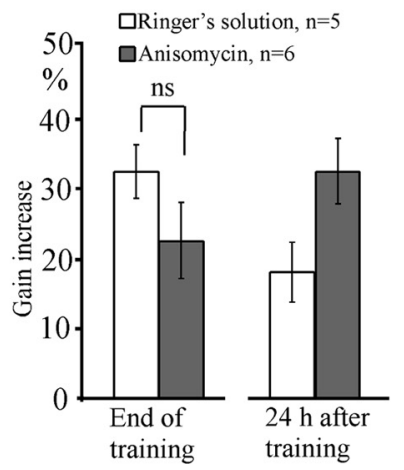

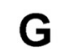

G

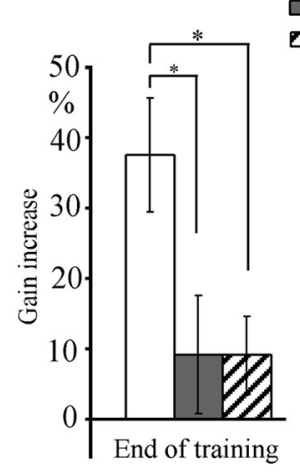

$\left(\mathrm{S}_{1 \mathrm{~h}}\right)$ $\square$ Ringer's solution, $\mathrm{n}=5$ $\square$ Anisomycin, $\mathrm{n}=6$ DActinomycin $\mathrm{D}, \mathrm{n}=6$

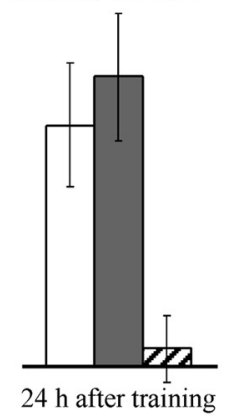

Figure 5. Effects of protein synthesis inhibition on adaptation induced by massed $(M)$ and spaced $\left(S_{1 \mathrm{~h}}\right)$ training. Anisomycin or control Ringer's solution was infused $4 \mathrm{~h}$ before the initiation of $M$ training and $1 \mathrm{~h}$ before the initiation of $S_{1 \mathrm{~h}}$ training. $A$, Photographs of Nissl-stained flocculus. The left two photographs show examples $24 \mathrm{~h}$ after infusions of Ringer's solution, and the right two photographs show examples $24 \mathrm{~h}$ after anisomycin infusions. Arrows show positions of the tip of infusion needle. The distance between the upper and lower photographs is $80 \mu \mathrm{m}$. Note that tissue damage by infusion was minimal, and the general cortical structure was not affected by infusions. FL, Flocculus; L, lateral; M, medial; PFL, paraflocculus. Scale bar, $200 \mu \mathrm{m}$. B, Averaged eye position traces obtained from the same mouse in $M$ training. Black dotted, thick, and thin curves show eye position traces at the start, end, and after $24 \mathrm{~h}$ of training, respectively, after infusion of Ringer's solution. Red curves similarly show eye position traces after anisomycin infusion. $C$, Similar to $B$ but for the data obtained during $S_{1 \mathrm{~h}}$ training. Eye position traces for $10-21$ cycles were averaged in $\boldsymbol{B}$ and $\boldsymbol{C}$. Scale bars, $1 \mathrm{~s}$ and $5^{\circ}$. $\boldsymbol{D}, \boldsymbol{E}$, Time course of HOKR adaptation and its retention after infusions of Ringer's solution (black circles), anisomycin (red circles), and actinomycin D (blue circles). $\boldsymbol{F}$, Comparison of gain increase at the end and $24 \mathrm{~h}$ after the end of M training. Unfilled and filled columns indicate data for Ringer's solution $(n=5)$ and anisomycin $(n=$ 6) infusions, respectively. $\boldsymbol{G}$, Similar to $F$, but for the gain increase after $S_{1 \mathrm{~h}}$ training. Data obtained after actinomycin D infusions $(n=6)$ were also shown by striped columns. ${ }^{*} p<0.05 ; \mathrm{ns}, p>0.05$ (Dunnett's test or Student's $t$ test). Error bars indicate SE.

floccular protein synthesis, which is not discussed further in this article.

\section{Neural mechanisms for memory trace transfer}

The training history-dependent transfer of memory trace of adaptation has been demonstrated by pharmacological shutdown experi- ments in the HOKR in mice (Shutoh et al., 2006) and horizontal vestibulo-ocular reflex (HVOR) in cats (Kassardjian et al., 2005) and monkeys (Anzai et al., 2010). One may speculate that flocculus shutdown would increase the spontaneous discharges of flocculus target vestibular nuclear neurons, alter the general performance of the HOKR/ HVOR neural circuitry, and consequently may affect HOKR/HVOR gains. However, we consider that such a possibility is unlikely, because effects of floccular lidocaine infusions were specific to the gains changed by adaptation (Nagao and Kitazawa, 2003; Shutoh et al., 2006; Anzai et al., 2010), and floccular CNQX infusions, which would only mildly affect the spontaneous discharges of Purkinje cells, induced similar effects on the adaptation as those of lidocaine (Kassardjian et al., 2005). These studies consistently suggest that the memory trace of adaptation induced by $1-2 \mathrm{~h}$ of training is located in the flocculus and that memory trace is transferred to the vestibular nuclei after days of training. However, the results of the present study suggest that the memory transfer could occur within 2.5 to $4 \mathrm{~h}$, when appropriate intervals are inserted to training.

Two possible mechanisms are listed for the transfer of the memory trace of adaptation. One is that the memory of adaptation may be initially formed in the floccular Purkinje cell synapses, which may secondarily induce plastic changes in the vestibular nuclei. Alternatively, the memory of adaptation may be formed independently in parallel within the flocculus and vestibular nuclei with different time courses. Results of the present study (Fig. 5) and those of the following four studies consistently suggest that the metabolic or electrical activity of Purkinje cells strongly influences the induction of plasticity of the vestibular or cerebellar nuclei that underlies memory transfer. Floccular infusions of $N^{\mathrm{G}}$-monomethylL-arginine, which blocks LTD/long-term potentiation (LTP) of parallel fiberPurkinje cell (pf-PC) synapses, depress both the acquisition and transfer of the memory of HOKR adaptation in mice (Shutoh et al., 2006). In mice genetically devoid of the substrate for the cyclic GMP-dependent protein kinase, which is uniquely concentrated in Purkinje cells, the acquisition of memory of HOKR adaptation is normal, but the memory transfer is specifically attenuated (Endo et al., 2009). In mice in which feedforward inhibitory inputs to Purkinje cells are removed genetically, the transfer of memory trace of HVOR adaptation is specifically impaired (Wulff et al., 2009). In rabbit eyeblink conditioning, the consolidation of conditioned responses is inhibited by tem- 
poral inactivation of the cerebellar cortex by muscimol infusion immediately following each training session, whereas the inactivation of cerebellar nuclei after training induced no inhibitory effect (Attwell et al., 2002; Cooke et al., 2004; Kellett et al., 2010).

\section{Pharmacological actions of anisomycin and actinomycin D}

In the present study, the mice received massed training (M) 4-5 $\mathrm{h}$ after floccular infusions of anisomycin and spaced training $\left(\mathrm{S}_{1}\right.$ h) 1-5 h after infusions of anisomycin or actinomycin D. Because inhibition of protein synthesis was demonstrated to reach maximum $1-5 \mathrm{~h}$ after infusions and then gradually decline (Rosenblum et al., 1993), the mice were trained at the time when the protein synthesis inhibition was maximum in both training protocols. It is also suggested that anisomycin may induce other depressant effects, e.g., facilitation of apoptosis, on neurons (Rudy et al., 2006) (but see Canal et al., 2007). We, however, consider that the nonspecific depressant effects of anisomycin were unlikely to explain the results of the present study for several reasons. First, anisomycin infused before the training did not alter the nonadapted HOKR gains (Table 2), floccular structure (Fig. 5), or number of floccular Purkinje cells (Table 3) for $24 \mathrm{~h}$ after infusions. Second, inhibitory effects of anisomycin were observed specifically in the adaptation induced by $S_{1 \mathrm{~h}}$ and not observed in the adaptation induced by $\mathrm{M}$ (Fig. 5), although both training protocols were carried out at similar period of time after infusions. Third, it is reported that both anisomycin and actinomycin D induce no appreciable changes in the general excitability of Purkinje cells, i.e., membrane resistance, resting membrane potentials, parallel fiber-induced EPSPs, or climbing fiber-induced $\mathrm{Ca}^{2+}$ spikes (Karachot et al., 2000, 2001).Together, we consider that a contribution of nonspecific depressant effects might be small in the inhibitory actions of anisomycin and actinomycin D on the adaptation induced by $S_{1}$. Thus, we suggest that the floccular protein synthesis inhibition caused by local drug application led to the reduced adaptation by $S_{1 \mathrm{~h}}$. Results of in vitro experiments suggest that the protein synthesis plays a role in LTD of pf-PC synapses, but whether it is related to induction (Karachot et al., 2001) or consolidation (Linden, 1996) is unclear.

A slight difference was recognized in the effects on adaptation between anisomycin, a translation inhibitor, and actinomycin $\mathrm{D}$, a transcription inhibitor. The depressive actions of anisomycin on memory transfer recovered $24 \mathrm{~h}$ after the training, while those of actinomycin D remained for $24 \mathrm{~h}$ (Fig. 5). One possibility for the different actions of these two drugs is the long-lasting effects of actinomycin D, which not only inhibits transcription but also binds to DNA. Another possibility is the necessity of transcription-dependent protein synthesis for memory transfer. A specific inhibition by transcription inhibitors (actinomycin D and $\alpha$-amanitin) was reported in Aplysia long-term behavioral sensitization (Castellucci et al., 1986; Sweatt and Kandel, 1989). The initial trigger of the gene cascade that induces long-term changes might not be activated in the presence of actinomycin D.

\section{Role of protein synthesis in memory transfer}

A number of pharmacological studies have suggested that protein synthesis is important in memory retention, but not necessary for memory acquisition (e.g., Squire, 1987; Squire and Kandel, 2000; Costa-Mattioli et al., 2009). Protein synthesis is necessary specifically for the long-term facilitation of the sensory-motor synapses and behavioral sensitization of gillwithdrawal reflex in Aplysia (Castellucci et al., 1986; Montarolo et al., 1986; Schacher et al., 1988). In the fear conditioning

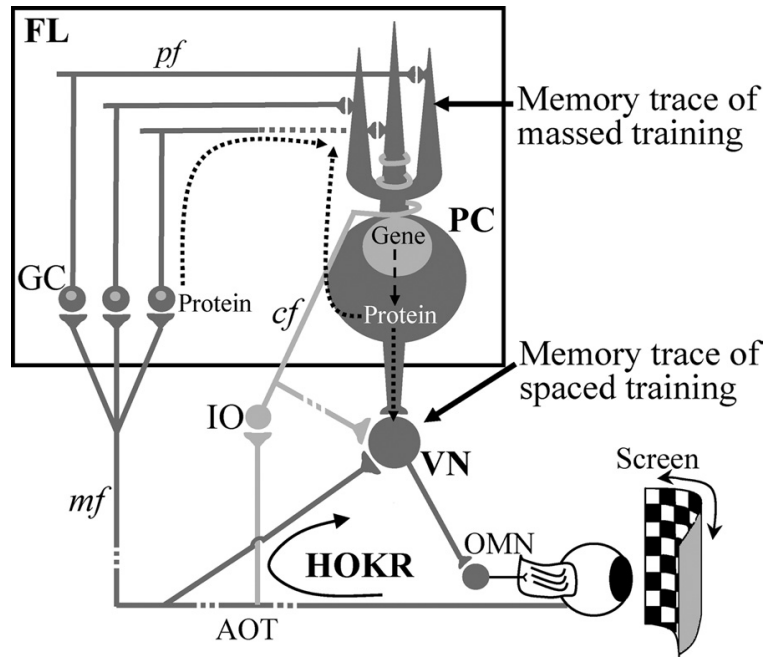

Figure 6. Neural circuitry for mouse HOKR and memory trace of adaptation induced by massed and spaced training. The optokinetic signals that drive the HOKR are mediated to the vestibular nuclei (VN) directly through mossy fiber $(\mathrm{mf})$ collateral inputs from the accessory optic tract (AOT) or indirectly through the axons of the flocculus (FL) Purkinje cells (PC). The retinal slip signals, which are necessary for the induction of HOKR adaptation, are mediated to the flocculus Purkinje cells through climbing fiber inputs ( $c f$ ). Our study reveals that the memory induced by massed training is maintained in $\mathrm{FL}$, whereas that induced by spaced training is maintained, most presumably, in VN. GC, Granule cells; 10, inferior olive; 0MN, oculomotor neurons; $p f$, parallel fibers.

of rats, anisomycin infusion in amygdala did not affect the acquisition of conditioned response but impaired its reconsolidation when anisomycin was infused $24 \mathrm{~h}$ after the conditioning (Nader et al., 2000; Debiec et al., 2002). Similar results were obtained in the inhibitory avoidance task of rats after hippocampal infusion of the amanitin (Katche et al., 2010). In rabbit eyeblink conditioning, infusions of anisomycin into the cerebellar interpositus nuclei depress both the acquisition and retention of the conditioned response (Bracha et al., 1998; Gomi et al., 1999). The role of protein synthesis has been suggested in the memory acquisition induced by the spaced training in the conditioning of the proboscis extension reflex of honey bees (Menzel et al., 2001) and in the contextual learning of fear conditioning in rats (Scharf et al., 2002).

The results of present study suggest that protein synthesis in the cerebellar cortex during the training period may play an important role for the induction of plasticity in the vestibular or cerebellar nuclei. What links the protein synthesized in the cerebellar cortex with the plasticity in the vestibular or cerebellar nuclei (Fig. 6)? One possibility is that proteins synthesized in Purkinje cells during training may be transported to their axon terminals and act postsynaptically on vestibular nuclear neurons. The destruction of the inferior olive induces depressive effects on the synaptic transmission in vestibular nuclei, which is assumed to be mediated through axonal transport (Ito et al., 1979; Karachot et al., 1987). Another possibility is that protein synthesis in the cerebellar cortex may be related to the plasticity of electrical properties of cerebellar Purkinje and other neurons. Protein synthesis is suggested to be involved in the late phase of LTD/LTP (Frey et al., 1988; Huang et al., 1996; Linden, 1996). Altered excitability of cerebellar cortical neurons caused by the absence of the late LTD/LTP may induce some depressant effects on the vestibular nuclear neurons that are closely connected with the cerebellar cortex. The other possibility is that the protein synthesis may be related to restructuring of cerebellar 
cortical neural circuitry. A decrease in the number of pf-PC synapses has been suggested in the rabbit cerebellar hemisphere after acquisition of eyeblink conditioning (Connor et al., 2009) and in the mouse flocculus after long-term HOKR adaptation (Nakadate et al., 2004). The reduced pf-PC synapses may decrease the tonic inhibitory drive of Purkinje cells on vestibular or cerebellar nuclear neurons. It has been suggested that the intrinsic excitability (Nelson et al., 2003) or responsiveness to mossy fiber inputs (Pugh and Raman, 2006; McElvain et al., 2010) of nuclear neurons is regulated by the inhibitory actions of Purkinje cells.

\section{References}

Anzai M, Kitazawa H, Nagao S (2010) Effects of reversible pharmacological shutdown of cerebellar flocculus on the memory of long-term horizontal vestibulo-ocular reflex adaptation in monkeys. Neurosci Res 68:191-198.

Attwell PJ, Cooke SF, Yeo CH (2002) Cerebellar function in consolidation of motor memory. Neuron 34:1011-1020.

Bracha V, Irwin KB, Webster ML, Wunderlich DA, Stachowiak MK, Bloedel JR (1998) Microinjections of anisomycin into the intermediate cerebellum during learning affect the acquisition of classically conditioned responses in the rabbit. Brain Res 788:169-178.

Canal CE, Chang Q, Gold PE (2007) Amnesia produced by altered release of neurotransmitters after intraamygdala injections of a protein synthesis inhibitor. Proc Natl Acad Sci U S A 104:12500-12505.

Castellucci VF, Frost WN, Goelet P, Montarolo PG, Schacher S, Morgan JA, Blumenfeld H, Kandel ER (1986) Cell and molecular analysis of longterm sensitization in Aplysia. J Physiol (Paris) 81:349-357.

Collewijn H, Grootendorst AF (1979) Adaptation of optokinetic and vestibulo-ocular reflexes to modified visual input in the rabbit. Prog Brain Res 50:771-781.

Connor S, Bloomfield J, LeBoutillier JC, Thompson RF, Petit TL, Weeks AC (2009) Eyeblink conditioning leads to fewer synapses in the rabbit cerebellar cortex. Behav Neurosci 123:856-862.

Cooke SF, Attwell PJ, Yeo CH (2004) Temporal properties of cerebellardependent memory consolidation. J Neurosci 24:2934-2941.

Costa-Mattioli M, Sossin WS, Klann E, Sonenberg N (2009) Translational control of long-lasting synaptic plasticity and memory. Neuron 61:10-26.

Debiec J, LeDoux JE, Nader K (2002) Cellular and systems reconsolidation in the hippocampus. Neuron 36:527-538.

Ebbinghaus HE (1885) Über das Gedächtnis. Reprinted as Memory: a contribution to experimental psychology (Ruger HA, Bussenius C, translators). New York: Teachers College-Columbia UP, 1913.

Endo S, Shutoh F, Dinh TL, Okamoto T, Ikeda T, Suzuki M, Kawahara S, Yanagihara D, Sato Y, Yamada K, Sakamoto T, Kirino Y, Hartell NA, Yamaguchi K, Itohara S, Nairn AC, Greengard P, Nagao S, Ito M (2009) Dual involvement of G-substrate in motor learning revealed by gene deletion. Proc Natl Acad Sci U S A 106:3525-3530.

Frey U, Krug M, Reymann KG, Matthies H (1988) Anisomycin, an inhibitor of protein synthesis, blocks late phases of LTP phenomena in the hippocampal CA1 region in vitro. Brain Res 452: 57-65.

Gomi H, Sun W, Finch CE, Itohara S, Yoshimi K, Thompson RF (1999) Learning induces a CDC2-related protein kinase, KKIAMRE. J Neurosci 19:9530-9537.

Huang YY, Nguyen PV, Abel T, Kandel ER (1996) Long-lasting forms of synaptic potentiation in the mammalian hippocampus. Learn Mem 3:74-85.

Ito M (1984) The cerebellum and neural control. New York: Raven.

Ito M (1989) Long-term depression. Annu Rev Neurosci 12:85-102.

Ito M (2001) Cerebellar long-term depression: characterization, signal transduction, and functional roles. Physiol Rev 81:1143-1195.

Ito M, Nisimaru N, Shibuki K (1979) Destruction of inferior olive induces rapid depression in synaptic action of cerebellar Purkinje cells. Nature 277:568-569.

Ito M, Sakurai M, Tongroach P (1982) Climbing fibre induced depression of both mossy fibre responsiveness and glutamate sensitivity of cerebellar Purkinje cells. J Physiol 324:113-134.

Jastreboff PW (1979) Evaluation and statistical judgment of neural responses to sinusoidal stimulation in cases with superimposed drift and noise. Biol Cybern 33:113-120.
Karachot L, Ito M, Kanai Y (1987) Long-term effects of 3-acetylpyridineinduced destruction of cerebellar climbing fibers on Purkinje cell inhibition of vestibulospinal tract cells of the rat. Exp Brain Res 66:229-246.

Karachot L, Shirai Y, Vigot R, Yamamori T, Ito M (2000) Rapidly turned over protein maintains metabotropic synaptic transmission in Purkinje cells. Neuroreport 11:2903-2906.

Karachot L, Shirai Y, Vigot R, Yamamori T, Ito M (2001) Induction of longterm depression in cerebellar Purkinje cells requires a rapidly turned over protein. J Neurophysiol 86:280-289.

Kassardjian CD, Tan YF, Chung JY, Heskin R, Peterson MJ, Broussard DM (2005) The site of a motor memory shifts with consolidation. J Neurosci 25:7979-7985.

Katche C, Bekinschtein P, Slipczuk L, Goldin A, Izquierdo IA, Cammarota M, Medina JH (2010) Delayed wave of c-Fos expression in the dorsal hippocampus involved specifically in persistence of long-term memory storage. Proc Natl Acad Sci U S A 107:349-354.

Katoh A, Kitazawa H, Itohara S, Nagao S (1998) Dynamic characteristics and adaptability of mouse vestibulo-ocular and optokinetic response eye movements and the role of flocculo-olivary system revealed by chemical lesions. Proc Natl Acad Sci U S A 95:7705-7710.

Katoh A, Kitazawa H, Itohara S, Nagao S (2000) Inhibition of nitric oxide synthesis and gene knockout of neuronal nitric oxide synthase impaired adaptation of mouse optokinetic response eye movements. Learn Mem 7:220-226.

Kellett DO, Fukunaga I, Chen-Kubota E, Dean P, Yeo CH (2010) Memory consolidation in the cerebellar cortex. PLoS One 5:e11737.

Lin CH, Yeh SH, Lu HY, Gean PW (2003) The similarities and diversities of signal pathways leading to consolidation of conditioning and consolidation of extinction of fear memory. J Neurosci 23:8310-8317.

Linden DJ (1996) A protein synthesis-dependent late phase of cerebellar long-term depression. Neuron 17:483-490.

McElvain LE, Bagnall MW, Sakatos A, du Lac S (2010) Bidirectional plasticity gated by hyperpolarization controls the gain of postsynaptic firing responses at central vestibular nerve synapses. Neuron 68:763-775.

Menzel R, Manz G, Menzel R, Greggers U (2001) Massed and spaced learning in honeybees: the role of CS, US, the intertrial interval and the test interval. Learn Mem 8:198-208.

Montarolo PG, Goelet P, Castellucci VF, Morgan J, Kandel ER, Schacher S (1986) A critical period for macromolecular synthesis in long-term heterosynaptic facilitation in Aplysia. Science 234:1249-1254.

Nader K, Schafe GE, Le Doux JE (2000) Fear memories require protein synthesis in the amygdala for reconsolidation after retrieval. Nature 406:722-726.

Nagao S (1983) Effects of vestibulocerebellar lesions upon dynamic characteristics and adaptation of vestibulo-ocular and optokinetic responses in pigmented rabbits. Exp Brain Res 53:36-46.

Nagao S (1988) Behavior of floccular Purkinje cells correlated with adaptation of horizontal optokinetic eye movement response in pigmented rabbits. Exp Brain Res 73:489-497.

Nagao S (1990) A non-invasive method for real-time eye position recording with an infrared TV-camera. Neurosci Res 8:210-213.

Nagao S, Kitazawa H (2003) Effects of reversible flocculus shutdown of the monkey flocculus on the retention of adaptation of the horizontal vestibulo-ocular reflex. Neuroscience 118:563-570.

Nakadate K, Shutoh F, Nagao S, Shigemoto R (2004) Reduction of synapse density after long-term adaptation of horizontal optokinetic response in the mouse flocculus. Neurosci Res 50 [Suppl 1]:P2-P092.

Nelson AB, Krispel CM, Sekirnjak C, du Lac S (2003) Long-lasting increases in intrinsic excitability triggered by inhibition. Neuron 40:609-620.

Pugh JR, Raman IM (2006) Potentiation of mossy fiber EPSCs in the cerebellar nuclei by NMDA receptor activation followed by postinhibitory rebound current. Neuron 51:113-123.

Rosenblum K, Meiri N, Dudai Y (1993) Taste memory: the role of protein synthesis in gustatory cortex. Behav Neural Biol 59:49-56.

Rudy JW, Biedenkapp JC, Moineau J, Bolding K (2006) Anisomycin and the reconsolidation hypothesis. Learn Mem 13:1-3.

Sakatani T, Isa T (2004) PC-based high-speed video-oculography for measuring rapid eye movements in mice. Neurosci Res 49:123-131.

Schacher S, Castellucci VF, Kandel ER (1988) cAMP evokes long-term facilitation in Aplysia sensory neurons that requires new protein synthesis. Science 240:1667-1669. 
Scharf MT, Woo NH, Lattal KM, Young JZ, Nguyen PV, Abel T (2002) Protein synthesis is required for the enhancement of long-term potentiation and long-term memory by spaced training. J Neurophysiol 87:2770-2777.

Shutoh F, Katoh A, Kitazawa H, Aiba A, Itohara S, Nagao S (2002) Loss of adaptability of horizontal optokinetic response eye movements in mGluR1 knockout mice. Neurosci Res 42:141-145.

Shutoh F, Katoh A, Ohki M, Itohara S, Tonegawa S, Nagao S (2003) Role of protein kinase $\mathrm{C}$ family in the cerebellum-dependent adaptive learning of horizontal optokinetic response eye movements in mice. Eur J Neurosci 18:134-142.

Shutoh F, Ohki M, Kitazawa H, Itohara S, Nagao S (2006) Memory trace of motor learning shifts transsynaptically from cerebellar cortex to nuclei for consolidation. Neuroscience 139:767-777.

Squire LR (1987) Memory and brain. Oxford: Oxford UP.

Squire LR, Kandel ER (2000) Memory: From mind to molecules. New York: Holt.

Sweatt JD, Kandel ER (1989) Persistent and transcriptionally-dependent increase in protein phosphorylation in long-term facilitation of Aplysia sensory neurons. Nature 339:51-54.

Wulff P, Schonewille M, Renzi M, Viltono L, Sassoè-Pognetto M, Badura A, Gao Z, Hoebeek FE, van Dorp S, Wisden W, Farrant M, De Zeeuw CI (2009) Synaptic inhibition of Purkinje cells mediates consolidation of vestibulo-cerebellar motor learning. Nat Neurosci 12:1042-1049. 